\title{
Met. Office rides out the storm
}

\section{- Once in a lifetime gales cause friction Met. Office set up internal inquiry}

\section{London}

BRITAIN's Secretary of State for Defence, $\mathrm{Mr}$ George Younger, has ordered an independent inquiry into the failure of the Meteorological Office to forecast the storms that caused extensive damage on the night of Thursday-Friday, 15-16 October. The director-general of the Meteorological Office, Dr John Houghton, has already set up an internal inquiry but the Ministry of Defence has appointed two external experts, Sir Peter SwinnertonDyer, chairman of the University Grants head of the meteorology department at the University of Reading, to examine the findings of the internal inquiry and report to the ministry.

There has been much made of the 'Met. Office' failure to predict the storms - and claims that the European Centre for Medium Range Weather Forecasting (ECMWF) had fared much better - but is this criticism fully justified? Mr Martin Morris, assistant director of central forecasting services at the Met. Office has outlined some of the problems faced by the forecasters during the week of 15 October. A shortage of in-situ data certainly hampered the forecasters, but they were also faced with conflicting predictions from their models.

A wide range of measurements are used to forecast the weather. These include a network of surface and upper-air observations of temperature, pressure, wind, humidity and cloudiness. Reports from ships and aircraft are also available, as are satellite data. A large number of observations are still received for 00:00 and 12:00 GMT. For this reason, forecasts start from Committee, and Professor Robert Pearse,

these times. However, significant numbers of observations are received for 06:00 and 18:00 GMT and satellites, aircraft and drifting buoys report at any time.

What were the medium- and shortrange weather forecasts saying about the weather conditions on 15-16 October? The diagram shows the actual track of the depression. At 12:00 GMT on Thursday, the centre of the low was at around $46.5^{\circ}$ $\mathrm{N}, 8^{\circ} \mathrm{W}$ in the Bay of Biscay with strong winds on the continental (south-east) side and a pressure of about 970 mbar. The Met. Office 12:00 GMT Tuesday forecast for 00:00 GMT Friday predicted the track of the depression well, but did not have the timing right (see table and figure). On Wednesday, the ECMWF model did not forecast the depression at all. The Met. Office fine-mesh model at 00:00 GMT on Thursday took the depression up the Channel, over East Anglia to the North Sea by 12:00 GMT (Friday) with little wind over inland areas but gales over the Channel and coastal areas. In contrast, the coarse-mesh model, run at a later time with more up-to-date data, produced an almost perfect forecast, with the low just south of Plymouth at 00:00 GMT on Friday at 966 mbar but the winds were not strong enough. With all this conflicting information, the forecaster compromised between the results of the fine-mesh and coarsemesh models and had difficulties forecasting the track and speed of motion of the depression and the wind strength. Forecasts on national and local radio, and television forecasts in the south, warned of strong winds - but they were not emphasized on national television.

The low moved north much more slowly

Forecasts from Tuesday onwards for 15-16 October

\begin{tabular}{|c|c|c|c|c|}
\hline Forecast & From & For & Description of low & Actual \\
\hline ECMWF & $\begin{array}{l}\text { 12:00 GMT } \\
\text { Tuesday }\end{array}$ & $\begin{array}{l}\text { 12:00 GMT } \\
\text { Thursday }\end{array}$ & $\begin{array}{l}\sim 47^{\circ} \mathrm{N} .23^{\circ} \mathrm{W} \\
968 \mathrm{mbar}\end{array}$ & $\begin{array}{l}\sim 46.5^{\circ} \mathrm{N} 8^{\circ} \mathrm{W} \\
971 \mathrm{mbar}\end{array}$ \\
\hline $\begin{array}{l}\text { Met. Office } \\
\text { (coarse-mesh) }\end{array}$ & & & $\begin{array}{l}\sim 47^{\circ} \mathrm{N} 11^{\circ} \mathrm{W} \\
970 \mathrm{mbar}\end{array}$ & \\
\hline ECMWF & $\begin{array}{l}\text { 12:00 GMT } \\
\text { Tuesday }\end{array}$ & $\begin{array}{l}\text { 12:00 GMT } \\
\text { Friday }\end{array}$ & Low over Ireland & $\begin{array}{l}\text { East of Scotland } \\
955 \text { mbar }\end{array}$ \\
\hline $\begin{array}{l}\text { Met. Office } \\
\text { (coarse-mesh) }\end{array}$ & $\begin{array}{l}\text { 12:00 GMT } \\
\text { Tuesday }\end{array}$ & $\begin{array}{l}\text { 00:00 GMT } \\
\text { Friday }\end{array}$ & $\begin{array}{l}\text { Took low to } \\
\sim 56^{\circ} \mathrm{N} 00^{\circ} \mathrm{W} \\
\text { at } 960 \mathrm{mbar}\end{array}$ & $\begin{array}{l}\text { Just south } \\
\text { of Cornwall } \\
\sim 956 \text { mbar }\end{array}$ \\
\hline ECMWF & $\begin{array}{l}\text { 12:00 GMT } \\
\text { Wednesday }\end{array}$ & $\begin{array}{l}\text { 12:00 GMT } \\
\text { Thursday }\end{array}$ & $\begin{array}{l}\text { Low not } \\
\text { forecast }\end{array}$ & \\
\hline $\begin{array}{l}\text { Met. Office } \\
\text { (fine-mesh) }\end{array}$ & $\begin{array}{l}00: 00 \text { GMT } \\
\text { Thursday }\end{array}$ & $\begin{array}{l}\text { 12:00 GMT } \\
\text { Friday }\end{array}$ & $\begin{array}{l}\text { Took low } \\
\text { up Channel, over } \\
\text { East Anglia into } \\
\text { North Sea ( } 957 \mathrm{mbar})\end{array}$ & \\
\hline (coarse-mesh) & $\begin{array}{l}00: 00 \text { GMT } \\
\text { Thursday }\end{array}$ & $\begin{array}{l}00: 00 \mathrm{GMT} \\
\text { Friday }\end{array}$ & $\begin{array}{l}\text { Low south } \\
\text { of Plymouth } \\
\text { at } 966 \mathrm{mbar}\end{array}$ & \\
\hline
\end{tabular}

than expected and so its intensification and increasing wind strength were not predicted. As it moved north, however, data from the observation networks alerted the Met. Office and warnings of severe weather were issued to the emergency services. Met. Office scientists were slightly aggrieved by claims that French and Dutch meteorologists had forecast the storms better as ECMWF and Met. Office data are used by the French and Dutch

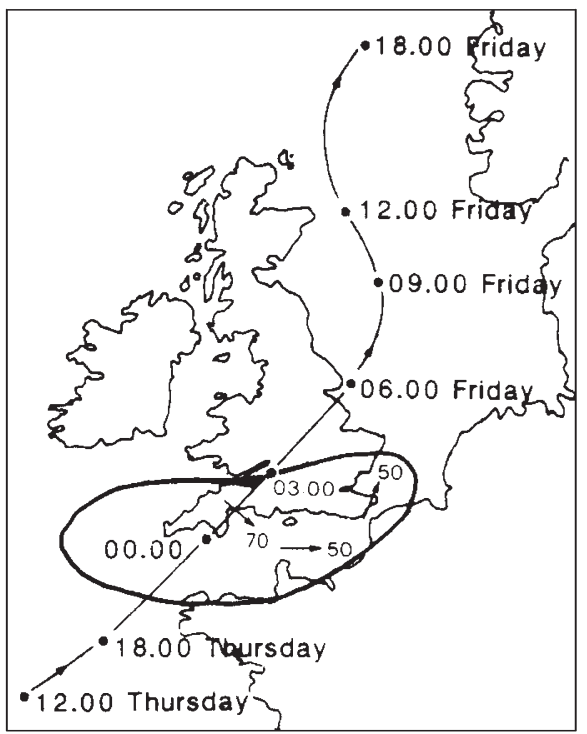

Actual track of depression, and area of 40-knot mean wind speed at 06:00 GMT on 16 October. Some maximum mean wind speeds (knots) are given - a 70 knot wind is Force 12

and their warnings of stormy weather over the Channel were apparently based on the Tuesday Met. Office and ECMWF medium-range forecasts for Thursday and Friday. The Met. Office itself issued warnings on Tuesday to its weather centres for the commercial services.

The information given by both the ECMWF and the fine- and coarse-mesh models was not consistent and so caused problems. The quality of the data used to specify the initial conditions for the models is of importance and the lack of a weather ship in the Bay of Biscay certainly did not help as little information could be gained about the strength of the winds. The weather ship Romeo, which used to occupy this station, was the victim of cuts last year. In the 1970s, there were eight weather ships in the west Atlantic; there are now only two. But as the models gave different forecasts it is not easy to say whether the missing weather ship data would have made much difference. It would have improved the initial data set but not necessarily the forecast. A careful look at the data received by these models is needed to assess why such conflicting forecasts were obtained.

Philippa Lloyd 